\title{
Batch pyrolysis of cotton stalks for evaluation of biochar energy potential
}

\author{
Rafat Al Afif ${ }^{1, *}$, S. Sean Anayah ${ }^{1}$, and Christoph Pfeifer ${ }^{1}$ \\ ${ }^{1}$ Institute of Chemical and Energy Engineering, Department of Material Sciences and Process \\ Engineering, University of Natural Resources and Life Sciences, Vienna, Muthgasse 107, \\ 1190 Vienna, Austria
}

\begin{abstract}
The thermal cracking of cotton stalks (CS) via pyrolysis was performed using a laboratory scale batch pyrolysis reactor. The effects of the final pyrolysis temperature varying from 300 to $800^{\circ} \mathrm{C}$ on the pyrolysis products distribution has been investigated. The maximum biochar yield of $46.5 \%$ was obtained at $400^{\circ} \mathrm{C}$. As the pyrolysis process temperature increased, the solid char product yield decreased. The lowest biochar yield of $28 \%$ was obtained at $800^{\circ} \mathrm{C}$. The largest higher heating value (HHV, $25.845 \mathrm{MJ} \mathrm{kg}^{-1}$ ) was obtained at $600^{\circ} \mathrm{C}$. All biochar samples produced between 500 and $700^{\circ} \mathrm{C}$ had an energy densification ratio of 1.41 , indicating a higher mass-energy density than the initial feedstock. A larger share of syngas and bio-oil were produced at higher temperatures, as estimated. Preferential selection of a char based on the energy yield would lead to a selection of the $400^{\circ} \mathrm{C}$ product, while selection based on the energy densification ratio would be for a product obtained between 500 to $700^{\circ} \mathrm{C}$.
\end{abstract}

\section{Introduction}

Cotton stalks (CS) are a common agricultural residue with little economic value. They may be utilised without direct competition to food or feed provision. Cotton waste production by weight is estimated at 2.9-3.8 times larger than commercial cotton production [1]. Global cotton production was estimated to around 29.136 million tons in 2017/2018 [2], therefore, CS constitutes a significant source of waste biomass [3] with roughly 80 million tons globally each year. The traditional method of disposal for waste biomass in less developed regions is usage as a fuel in simple cooking stoves or direct incineration on farm-land. These methods are associated with high local air pollution [4]. Therefore, exploring alternative methods for environmentally friendly disposal of CS is important. Furthermore, these significant quantities of CS waste from agricultural production are a potential source of revenue. Other risks associated with cotton waste such as farm hygiene by pesticide remnants and soil-borne pathogens can also be addressed. In summary, utilizing CS has the potential to be a significant source of energy and an opportunity to reduce the environmental issues and financial costs associated with disposal [5].

\footnotetext{
* Corresponding author: rafat.alafif@boku.ac.at
} 
Several studies have encouraged the conversion of agricultural residues into useful products as a method of carbon sequestration rather than their direct combustion. Some of these useful products include paper, boards, biofuels [6-10], and biochar, which is a solid carbon-rich residue left after pyrolysis of carbonaceous biomass. Biochar can be readily used as a biofuel feedstock for domestic use and in existing coal power plants, but also as fuel to heat the pyrolysis process $[11,12]$. Utilization of cotton waste as an energy feedstock has become a subject of many studies in recent years [13-16]. Researchers have generally focused on the production of biogas, ethanol and the production of fuel pellets or briquettes. Past pyrolysis experimentation of CS has been performed for the coproduction of char, oil, and gas $[17,18]$. The liquid bio-oil and synthetic gas have direct use as a fuel or as an intermediate pre-treatment step for converting biomass into a high-energy liquid, which can be further processed for power, heat, biofuels and chemicals [19]. Venkatesh et al. investigated biochar production technology for conversion of CS. They indicated that CS biochar produced at $450-500^{\circ} \mathrm{C}$ showed the greatest potential for use as a soil amendment to improve the fertility of rainfed soils as well as to sequester carbon [20]. However, since pyrolysis of CS is still in its developing stage, many challenges such as the energy evaluation of biochar stand in the way of substantial implementation of the process. Therefore, in the present work, we investigate the conversion of CS into pyrolysis char and heat energy with the purpose of assessing the effect of different temperatures on the energy production via pyrolysis end products with focus on the biochar.

\section{Materials and methods}

\subsection{Material}

Cotton stalk samples were obtained from Syrian agricultural production. The CS was a mixture of small pieces of the main stem, branches, burs, boll rinds, bracts, and peduncles in various shapes and sizes (see Fig. 1). It was ground and sieved to produce a granular powder with a particle size of $1-3 \mathrm{~mm}$. The cotton stalk employed herein contained $44.75 \%$ $\mathrm{C}, 5.75 \% \mathrm{H}, 48.57 \% \mathrm{O}, 0.9 \% \mathrm{~N}$, and $0.03 \% \mathrm{~S}$ on a dry ash free basis (DAF). Proximate analysis performed on a dry sample indicated that it contained $76.44 \%$ volatile matter and $5.08 \%$ ash, resulting in a fixed carbon amount of $18.48 \%$. The HHV of raw CS was $18.32 \mathrm{MJ} \mathrm{kg}^{-1}$. The ultimate and proximate analysis of composition and HHV of the raw CS feedstock and of each pyrolysis char was determined in accordance with ASTM standards [21].

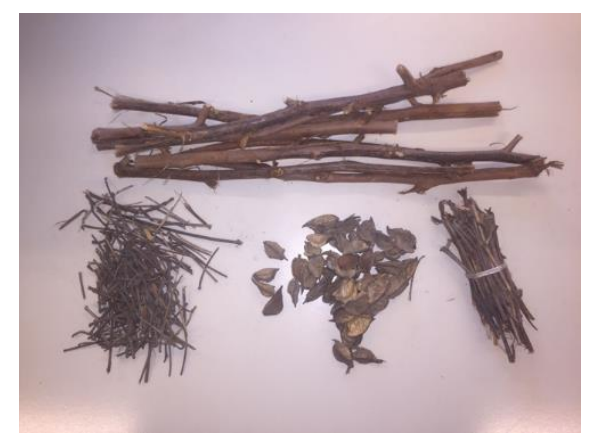

Fig. 1. Air dried cotton stalk samples. 


\subsection{Experimental procedure}

CS pyrolysis experiments were conducted using a laboratory batch pyrolysis reactor. The stainless-steel reactor was a batch design which was cylindrical and airtight. The reactor lid measured $18 \mathrm{~cm}$ wide and $2 \mathrm{~cm}$ high, the holding container $14 \mathrm{~cm}$ wide and $12 \mathrm{~cm}$ high. The reactor was modified with a steel pipe connected to a valve to allow input of $\mathrm{N}_{2}$ to create an $\mathrm{O}_{2}$ free environment and an output of syngas and liquid coproducts released during experimentation. Six temperature settings for pyrolysis were selected: $300^{\circ}, 400^{\circ}, 500^{\circ}, 600^{\circ}$, $700^{\circ}$, and $800^{\circ} \mathrm{C}$. The residence time for the pyrolysis of each sample was fixed at 30 minutes. For each pyrolysis experiment the temperature was set at each respective temperature and residence time. Approximately 20 grams ( \pm 0.5 grams) of the prepared CS was loaded in the steel reactor for each run. After loading the CS and before the start of each run, $\mathrm{N}_{2}$ was purged into the reactor at a rate of roughly 0.5 litres min- 1 for fifteen minutes. Following the initiation of each run, $\mathrm{N}_{2}$ input into the reactor continued until the furnace reached the desired temperature. At the desired temperature $\mathrm{N}_{2}$ input stopped, the tube removed, and the same inlet was used as an outlet for the gaseous and liquid products. The heating rate was calculated by measuring the length of time to reach the desired temperature from ambient room temperature at $25^{\circ} \mathrm{C}$, yielding an estimated heating rate $13 \mathrm{~K}$ per minute. During each experiment the gaseous products were allowed to escape, while the liquid condensates (bio-oil) were collected in a small container. After pyrolysis experimentation, the solid char products were collected from the reactor, weighed, and stored in airtight containers. The syngas and bio-oil yields were calculated by estimation based on literature. Each experiment was conducted at least twice to ensure that the pyrolysis tests yielded similar results and the reported yield is the average. Because the standard deviations for char yields are $2 \%$ or lower, duplicate experiments were deemed satisfactory as suggested by Louwes et al [22]. Each sample at its respective pyrolysis temperature was given a sample ID as designated in Table 1.

Table 1. Design of pyrolysis experimentation with heating rate $13^{\circ} \mathrm{C} / \mathrm{min}$ and Residence Time $30 \mathrm{~min}$.

\begin{tabular}{|c|c|c|c|c|}
\hline $\begin{array}{c}* \text { Sample } \\
\text { ID }\end{array}$ & Initial Mass (g) & $\begin{array}{c}\text { Nitrogen Flow } \\
\left(\text { liters } \mathbf{~ m i n}^{-1}\right)\end{array}$ & Temperature ( $\left.^{\circ} \mathbf{C}\right)$ & Replication \\
\hline C1 & 20 & 0.5 & 300 & 3 \\
\hline C2 & 20 & 0.5 & 400 & 3 \\
\hline C3 & 20 & 0.5 & 500 & 3 \\
\hline C4 & 20 & 0.5 & 600 & 2 \\
\hline C5 & 20 & 0.5 & 700 & 2 \\
\hline C6 & 20 & 0.5 & 800 & 2 \\
\hline
\end{tabular}

*Sample ID's are denoted by $\mathrm{C}$ for $\mathrm{CS}$ char and subsequently identified numerically from 1-6. $\mathrm{C} 1: 300^{\circ} \mathrm{C}, \mathrm{C} 2: 400^{\circ} \mathrm{C}, \mathrm{C} 3: 500^{\circ} \mathrm{C}, \mathrm{C} 4: 600^{\circ} \mathrm{C}, \mathrm{C} 5: 700^{\circ} \mathrm{C}, \mathrm{C} 6: 800^{\circ} \mathrm{C}$.

The input of biomass was compared to the quantity of outputs. $100 \%$ conversion efficiency was assumed, as well as a conversion efficiency with a gas loss of $16 \%$. Char yield 
was calculated with equation (1) in which $M_{C}$ is the mass of the produced char, $M_{F e e d}$ is the mass of the feedstock, and $Y_{C h a r}$ is the calculated percentage yield [23]:

$$
Y_{\text {Char }}(\%)=\frac{M_{C}}{M_{\text {Feed }}} \cdot 100
$$

Oil yield $\left(\mathrm{Y}_{\mathrm{oil}}\right)$ was determined from experiments and the gas yield $\left(Y_{\text {gas }}\right)$ has been calculated according to equation 2 where $Y_{o i l}$ and $Y_{\text {gas }}$ are defined analogous to equation 1 .

$$
Y_{\text {Gas }}=100-Y_{\text {Char }}-Y_{\text {oil }}
$$

The energy yield was calculated from the mass yield, and the lower heating values (LHV) of the char and feedstock according to equation 3.

$$
Y_{\text {Energy }}(\%)=Y_{\text {Char }} \frac{L H V_{\text {Char }}}{L H V_{\text {Feed }}}
$$

The mass energy density or the, energy densification ratio, was calculated by equation 4 from the mass yield and energy yield

$$
\text { Energy densificationratio }=\frac{Y_{\text {Energy }}}{Y_{\text {Char }}}
$$

A simple energy balance for the pyrolysis experiments at each temperature was developed from the average product yields under the assumption that product losses were negligible. The chemical energy $\left(E_{C h e m}\right)$ of the char was calculated by multiplying the char yield ( $\left.Y_{\text {Mass }}\right)$ by the LHV of the chars at each respective temperature according to Equation 5.

$$
E_{\text {Chem }}=Y_{\text {Char }} \cdot L H V
$$

The bio-oil and syngas chemical energy were estimated from the energy simulation heat balance

\section{Results and discussions}

\subsection{Products distribution}

Pyrolysis yields (wt\%) of CS at different temperatures are shown in Fig. 2. Overall, increasing the process temperature results in a decrease of char yield and an increased yield of liquid and gases. Char yield fraction varied from 86.5 to $28.0 \%$ for all samples with the highest value for sample $\mathrm{C} 1$ at $300^{\circ} \mathrm{C}$, decreasing with increase of the pyrolysis temperature to the lowest char yield in sample $\mathrm{C} 6$ at $800^{\circ} \mathrm{C}$. It has to mentioned that at $300^{\circ} \mathrm{C}$ it is rather torrefaction than pyrolysis and this leads to a minimum of volatiles being released. A similar study conducted earlier investigated the char yield of other feedstocks such as wheat and rice straw, corn stover, and rape stalk with results indicating a similar proportional char yield 
reduction at their respective temperatures. For example, the yield of rice straw was reduced from $74.49 \%$ at $300^{\circ} \mathrm{C}$ to $35.59 \%$ at $600^{\circ} \mathrm{C}$ which is within $2 \%$ of the yield of CS char at those temperatures [24].

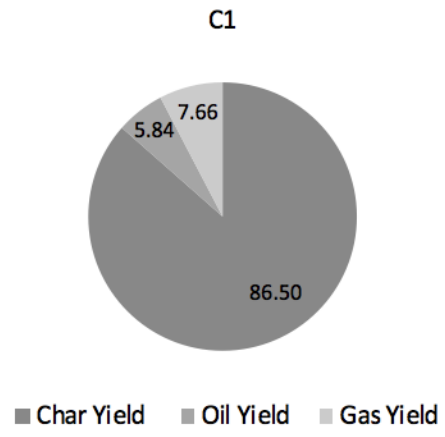

C3

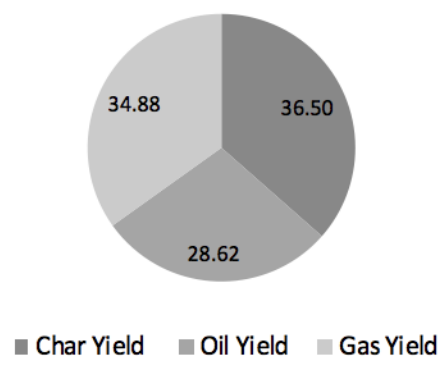

C5

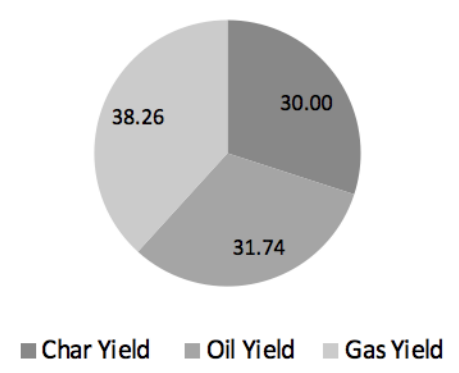

C2

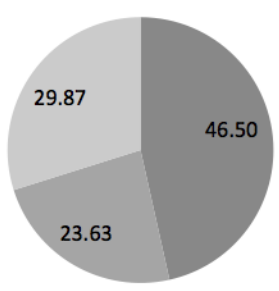

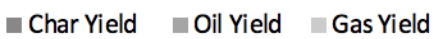

C4

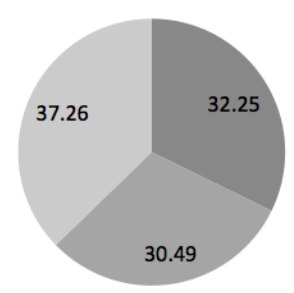

" Char Yield $\quad$ Oil Yield $\backsim$ Gas Yield

C6

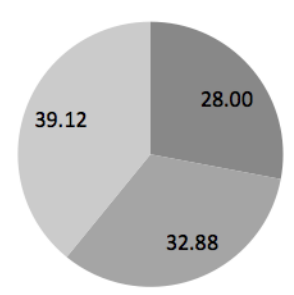

" Char Yield $\quad$ - Oil Yield $\quad$ Gas Yield

Fig. 2. Yields of pyrolysis products at each temperature.

The lowest bio-oil and syngas yield occurred at $300^{\circ} \mathrm{C}$ with $5.84 \%$ and $7.66 \%$, respectively were estimated on previous experiments as well as on literature. This can be attributed to the fact that sample $\mathrm{C} 1$ at $300^{\circ} \mathrm{C}$ had not undergone full carbonization and therefore produced minimal gaseous and liquid products while yielding the largest quantity of solid product at $86.5 \%$. The largest bio-oil and syngas yields occurred at $800^{\circ} \mathrm{C}$ with $32.88 \%$ and $39.12 \%$, respectively, but also with the lowest yield of char at $28 \%$. At higher temperatures, the increase in gas yield can be attributed to the secondary reactions of the pyrolysis vapors within the reactor, while the decreasing char yield is attributed to the 
primary decomposition of the CS feedstock and the secondary decomposition of char at higher temperatures. During secondary decomposition of char at higher temperatures, non-condensable syngas products also contribute to elevated gas yield which occurs parallel to increasing temperature $[25,26]$. Preferential selection of pyrolysis temperature is dependent on prioritizing yield distribution. In this study, our main objective is a higher char content, and therefore, the yield at $400^{\circ} \mathrm{C}$ would be deemed optimal.

\subsection{Solids Energy Yield, and Mass Energy Density}

The char energy yield of the samples is displayed in Table 2. It is a comparison of the energy retained after pyrolysis with the energy content of the initial biomass feedstock.

Table 2. Mass and Energy yields of CS and char samples.

\begin{tabular}{|c|c|c|c|c|}
\hline Sample ID & $\begin{array}{c}\text { Solids Mass } \\
\text { Yield (\%) }\end{array}$ & $\begin{array}{c}\text { Solids Energy } \\
\text { Content (HHV) (MJ } \\
\left.\mathbf{k g}^{-1}\right)\end{array}$ & $\begin{array}{c}\text { Solids } \\
\text { Energy Yield } \\
\mathbf{( \% )}\end{array}$ & $\begin{array}{c}\text { Energy } \\
\text { Densification } \\
\text { Ratio }\end{array}$ \\
\hline CS & 100 & 18.32 & - & 1 \\
\hline C1 & 86.5 & 19.63 & 92.68 & 1.07 \\
\hline C2 & 46.5 & 25.40 & 64.48 & 1.39 \\
\hline C3 & 36.5 & 25.765 & 51.31 & 1.41 \\
\hline C4 & 32.25 & 25.855 & 45.50 & 1.41 \\
\hline C5 & 30 & 25.80 & 42.24 & 1.41 \\
\hline C6 & 28 & 25.61 & 39.14 & 1.40 \\
\hline
\end{tabular}

For char samples at all temperatures the energy yield was greater than the mass yield. The highest chemical efficiency was exhibited in sample $\mathrm{C} 1$ at $92.68 \%$, however, this sample did not undergo full carbonization and was therefore eliminated from consideration. The second highest chemical efficiency was found in sample $\mathrm{C} 2$ at $64.48 \%$ which underwent pyrolysis at $400^{\circ} \mathrm{C}$, while the lowest was found in sample C6 at $39.14 \%$ which underwent pyrolysis at $800^{\circ} \mathrm{C}$. The energy densification ratios of all samples increased with increasing pyrolysis temperature. In comparison with the energy density of the feedstock with a value of 1 , samples C3, C4, and C5 all had the highest energy densities at 1.41. This signifies that at a lower mass, there is an increase in energy content, producing a higher quality product. Preferential selection of a sample based on the energy yield would lead to a selection of sample $\mathrm{C} 2$ at $400^{\circ} \mathrm{C}$, while selection based on the energy densification ratio would be the samples C3, C4, and C5 which underwent pyrolysis between $500^{\circ} \mathrm{C}$ and $700^{\circ} \mathrm{C}$. A study by Poudel et al. reports a similar decrease in energy yield from $95 \%$ at $150^{\circ} \mathrm{C}$ to $25 \%$ at $600^{\circ} \mathrm{C}$ during pyrolysis of food waste [27].

\section{Conclusions}


Temperature has an influence on the mass and energy yield from pyrolysis for cotton stalks. The largest char yield was obtained at $300^{\circ} \mathrm{C}$, whereas the highest yields of gas and oil were estimated at $800^{\circ} \mathrm{C}$. The char with the highest measured $\mathrm{HHV}$ was determined at $600^{\circ} \mathrm{C}$ and char samples between 500 and $700^{\circ} \mathrm{C}$ had a significantly higher mass-energy density (1.41) than the initial feedstock. However, the evaluation showed that the temperature of $800^{\circ} \mathrm{C}$ would be most optimal for deriving energy from the bio-oil because its share of energy is higher than that of the char or gas share. A temperature of $400^{\circ} \mathrm{C}$ would be most optimal for deriving energy from the char because its share of energy is higher than that of the bio-oil or gas share. Meanwhile, temperatures of 600,700 , and $800^{\circ} \mathrm{C}$ produce the largest share of energy from gas out of all the temperatures, although the shares are lower than the char and bio-oil shares. Therefore, a determination of appropriate pyrolysis temperature would likely be dependent on prioritization of higher char or bio-oil yield. Factors contributing to preferentially selecting a higher char or bio-oil yield are transportation and storage costs, end-use of products, the price of utilizing each product, as well as others.

The authors would like to thank Prof. Dr. Martin Wendland for his comments that greatly improved the manuscript.

\section{References}

1. R. Mythili, P. Venkatachalam, J. Sci. Ind. Res. 72, 1, 58-61 (2013)

2. J. Johnson, S. MacDonald, L. Meyer, L. Stone, The world and United States cotton outlook (Agricultural Outlook Forum, U.S. Department of Agriculture, 2018)

3. M. A. Egbuta, S. McIntosh, D. L. E. Waters, T. Vancov, L. Liu, Molecules 22, 1, 1-25 (2017)

4. P. Fu, S. Hu, J. Xiang, L. Sun, S. Su, S. An, Journal of Analytical and Applied Pyrolysis 97, 130-136 (2012)

5. I. Hamawand, G. Sandell, P. Pittaway, S. Chakrabarty, T. Yusaf, G. Chen, S. Seneweera, S. Al-Lwayzy, J. Bennett, J. Hopf, Renewable and Sustainable Energy Reviews 66, 435-448 (2016)

6. Y. Fahmy, T. Y. A. Fahmy, F. Mobarak, M. El-Sakhawy, M. H. Fadl, International Journal of Chem. Tech. Research 2, 424-448 (2017)

7. D. Kaur, N. K. Bhardwaj, R. K. Lohchab, Waste Management 60, 127-139 (2017)

8. T. Y. A. Fahmy, F. Mobarak, Cellulose 20, 3, 1453-1457 (2013)

9. R. Al Afif, B. Linke, Energy 171, 1046-1052 (2019)

10. R. Al Afif, T. Amon, Energy Sources, Part A: Recovery, Utilization, and Environmental Effects 10, 1080 (2018)

11. T. H. Mwampamba, M. Owen, M. Pigaht, Energy Sustainable Dev. 17, 158-170 (2013)

12. S. Schaffer, T. Pröll, R. Al Afif, C. Pfeifer, Biomass and Bioenergy, 120 (2018)

13. M. Ertas, B. Acemioglub, M. H. Alma, M. Usta, J. Hazardous Mater. 183, 421-427 (2010)

14. W. Coates, Biomass and Bioenergy 18, 201-208 (2000)

15. X. Yua, L. Ma, B. Wen, D. Zhou, M. Kuang, W. Yang, Z. Cui, Bioresource Technology, 207, 293-301 (2016)

16. M. Adl, K. Sheng, A. Gharibi, Applied Energy 2017, 251-260 (2012)

17. T. Pröll, R. Al Afif, S. Schaffer, C. Pfeifer, Energy Procedia 114, 6057-6066 (2017) 
18. X. Xianjun, L. Hui, M. Peiyong, S. Yadong, H. Yunlong, L. Tao, Energy Procedia 66, 297-300 (2015)

19. S. A. Shah, M. Zeeshan, M. Z. Farooq, N. Ahmed, N. Iqbal, Renewable Energy 130, 238-244 (2019)

20. G. Venkatesh, B. Venkateswarlu, K. A. Gopinath, Indian J. Dryland Agric. Res. \& Dev. 28, 1, 48-57 (2013)

21. ASTM D5865-13. ASTM International, West Conshohocken 10, 1520 (2013)

22. A. C. Louwes, L. Basile, R. Yukananto, J. C. Bhagwandas, E. A. Bramer, G. Brem, Biomass and Bioenergy 105, 116-126 (2017)

23. T. G. Bridgeman, J. M. Jones, I. Shield, P. T. Williams, Fuel 87, 6, 844-856 (2008)

24. Z. He, H. Zhang, H. Tewolde, M. Shankle, Chemical Characterization of Cotton Plant Parts for Multiple Uses. Agric. Environ. Lett. 10, 2134 (2017)

25. F. L. Aquino, Office of Graduate Studies of Texas A\&M University (2007)

26. A. E. Pütün, N. Özbay, E. P. Önal, E. Pütün, Fuel Processing Technology 86, 11, 1207-1219 (2005)

27. J. Poudel, T. Ohm, S. C. Oh, Fuel 140, 275-281 (2015) 